\title{
Pengaruh Pendekatan Pembelajaran Realistic Mathematics Education dan Contextual Teaching Learning terhadap Pemahaman Konsep dan Komunikasi Matematis
}

\author{
Mara Samin Lubis ${ }^{*}$ \\ marasmin@yahoo.com
}

\begin{abstract}
This research was conducted to see the extent of students' understanding of concepts and mathematical communication after being treated with learning using the RME and CTL approaches. The approach used in this research is quantitative with a type of quasiexperimental research. The population as well as the sample in this study were 2 classes with a total of 70 XI MAS PAB 2 Medan Estate students. Next to find out the understanding of concepts and mathematical communication students are given a description test. To process the data obtained using ANACOVA; The results of the data analysis test concluded: the level of understanding of the concepts of students who were treated with the RME approach was lower in influence than students who were treated with the CTL approach. The mathematical communication of students who were treated with the RME approach was less influential than students who were treated with the CTL approach. The level of understanding of mathematical concepts and communication of students who were treated with the RME learning approach was lower in influence than students who were treated with the CTL learning approach. Data analysis concluded that there was an interaction effect of applying the learning approach to students' understanding of concepts and mathematical communication.
\end{abstract}

Keywords: CTL; RME; learning approaches; concept understanding; mathematical communication.

\begin{abstract}
Abstrak
Penelitian ini dilaksanakan untuk melihat sejauh mana tingkat pemahaman konsep siswa dan komunikasi matematis setelah diberi perlakuan pembelajaran dengan pendekatan $R M E$ dan $C T L$. Pendekatan yang digunakan dalam penelitian ini adalah kuantitatif dengan jenis penelitian quasi eksperimen. Populasi sekaligus sampel dalam penelitian ini adalah 2 kelas dengan jumlah 70 orang siswa XI MAS PAB 2 Medan Estate. Selanjutnya untuk mengetahui pemahaman konsep dan komunikasi matematis siswa diberikan tes uraian. Untuk mengolah data yang didapatkan digunakan ANACOVA; Hasil uji analisis data menyimpulkan: tingkat pemahaman konsep siswa yang diberi perlakuan pendekatan $R M E$ lebih rendah pengaruhnya daripada siswa yang diberi perlakuan pendekatan CTL. Komunikasi matematis siswa yang diberi perlakuan pendekatan $R M E$ lebih rendah pengaruhnya daripada siswa diberi perlakuan pendekatan $C T L$. Tingkat pemahaman konsep dan komunikasi matematis siswa yang diberi perlakuan pendekatan pembelajaran $R M E$ lebih rendah pengaruhnya daripada siswa yang diberi perlakuan pendekatan pembelajaran CTL. Analisis data menyimpulkan terdapat pengaruh interaksi penerapan pendekatan pembelajaran terhadap pemahaman konsep dan komunikasi matematis siswa.
\end{abstract}

Kata Kunci: $C T L$; $R M E$; pendekatan pembelajaran; pemahaman konsep; komunikasi matematis

*Correspondence:

Email: marasmin@yahoo.com 


\section{PENDAHULUAN}

Kemajuan pendidikan merupakan tonggak utama majunya suatu bangsa, oleh karena itu setiap periode pemerintahan menjadi persoalan pendidikan sebagai masalah yang urgen yang harus ditangani secara serius dan merupakan skala prioritas pemerintah. Pendidikan akan bermutu, apabila bidang keilmuan, materi yang dipelajari sesuai dengan perkembangan dan proses dalam pembelajaran berjalan dengan aman dan kondusif. Salah satu bidang ilmu yang mendapat perhatian besar dalam dunia pendidikan adalah matemtika. Karena matematika merupakan salah satu ilmu pendidikan yang mempunyai peranan penting dalam memecahakan permasalahan dikehidupan sehari-hari, matematika merupakan bahasa simbol yang mengandung makna bahwa matematika bersifat universal (Firdaus, 2017).

Perkembangan matematika dari tahun ketahun akan terus meningkat sesuai dengan kebutuhan dan tuntutan zaman. Matematika memegang peranan yang sangat penting dalam sistem pendidikan di seluruh dunia, matematika dianggap mampu meningkatkan pengetahuan siswa (Abdullah, A. H., Mokhtar, M., Halim, N. D. A., Ali, D. F., Tahir, L. M., \& Kohar, 2017). Oleh karenanya, pentingnya mata pelajaran matematika dalam setiap jenjang pendidikan dan pentingnya untuk belajar matematika sudah tidak diragukan lagi.

Pembelajaran matematika sangat diperlukan karena terkait dengan penanaman konsep pada peserta didik (Chotimah, S., Bernard, M., \& Wulandari, 2018). Penanaman konsep pada peserta didik harus dibiasakan. Karena sejatinya pembelajaran matematika saat ini diarahkan untuk mengembangkan berbagai kemampuan diantaranya kemampuan pemahaman konsep, kemampuan komunikasi, kemampuan koneksi, kemampuan induksi dan kemampuan yang lainnya. Salah satu kemampuan yang harus dimiliki siswa adalah kemampuan pemahaman konsep. Siswa perlu diberikan pemahaman mengenai konsep matematika untuk memudahkan para siswa dalam mengikuti kegiatan pembelajaran. Pemahaman konsep untuk setiap materi penting dimiliki setiap siswa karena dapat membantu proses mengingat dan menjadi lebih mudah dalam mengerjakan soal-soal matematika yang memerlukan banyak rumus (Simamora, R. E., Sidabutar, D. R., \& Surya, 2017). Kemampuan pemahaman konsep merupakan modal dasar dan tahapan penting bagi seorang siswa dalam rangkaian pembelajaran matematika. Kemampuan memahami konsep dalam matematika merupakan salah satu kecakapan atau kemahiran matematika yang harus dicapai oleh seiswa dalam pembelajaran matematika.

Selain kemampuan pemahaman konsep, kemampuan komunikasi matematis juga dianggap penting dalam pembelajaran matematika, hal tersebut tertuang dalam Permen 22 Tahun 2006 tentang Standar Kompetensi Kelulusan dalam bidang matematika. Komunikasi matematik merupkan salah satu 
kemampuan matemaika yang sering dipergunakan dalam kehidupan sehari-hari. Komunikasi sangat besar peranannya dalam matematika, karena saat para siswa mengkomunikasikan ide, konsep matematika, mereka belajar mengklarifikasi, memperhalus dan menyatukan pemikiran (Rustam, A., \& Handayani, 2017). Komunikasi matematis merupakan media atau sarana dalam menyampaikan pengetahuan matematika dalam mempelajari dan menumbuhkan pengetahuan matematika (Guerreiro, 2008).

Hasil penelitian menyimpulkan kemampuan komunikasi siswa dalam mengemukakan ide atau gagasan, keterkaitan satu konsep dengan konsep lain masih rendah dengan bahasa sendiri (Waldron, 2017). Selain itu dalam penelitian lain juga ditemukan bahwa siswa tampaknya kesulitan mengartikulasikan alasan dalam memahami suatu bacaan (Osterholm, 2006). Mayoritas dari siswa tidak menuliskan solusi masalah dengan menggunakan bahasa matematis yang benar (Tong, D. H., \& Loc, 2017).

Berdasarkan penelitian-penelitian tersebut, perlu untuk mendindaklanjuti kedalam kondisi dilapangan. Kondisi dilapangan saat ini, guru kurang kreatif dalam mengelola kelas, masih banyak yang menggunaan pola-pola lama dalam pembelajaran di kelas, pendekatan pembelajaran yang diterapkan saat ini kurang memberikan kesempatan kepada siswa untuk menyampaikan ide-ide mereka sendiri. Guru juga kurang memberikan kesempatan siswa untuk aktif dalam proses membangun pengetahuannya sehingga siswa kurang dapat memiliki kemampuan komunikasi matematik dan kurang terbiasa berkomunikasi secara matematis baik lisan ataupun tulisan. Padahal sejatinya guru adalah fasilitator yang mampu dan harus menciptakan suasana belajar yang kondusif, menyediakan fasilitas, dan lainnya, karena peran guru sebagai manajer pembelajaran.

Untuk membantu siswa mengatasi kesulitan dalam belajar, Alfeld menjelaskan seseorang anak dikatakan telah mempunyai pemahaman konsep yang baik, jika anak telah dapat berbuat seperti; (1) dapat mengutarakan konsep, masalah kedalam fakta matematika yang sudah difahami. (2) dapat menghubungkan antara antara konsep dengan fakta secara logis. (3) dapat menghubungkan sesuatu kedalam hal yang baru berdasarkan apa yang ia ketahui. (4) dapat mengidentifikasi pola-pola yang ada kedalam matematika sehingga membuat segala pekerjaannya berjalan dengan baik dan lebih mudah (Syarifatunnisa. A, 2013).

Selanjutnya untuk melihatkan kemampuan komunikasi matemais siswa, menurut NCTM yang dimaksud kegiatan di dalam kemampuan komunikasi matematis mulai dari tingkat taman kanak-kanak hingga sekolah menengah keatas yaitu: (1) Menggabungkan dan membangun ide-ide serta pemahaman matematika melalui komunikasi, (2) Menyampaikan dengan jelas ide-ide matematika yang telah dimiliki kepada teman kelas, guru, dan orang lain, (3) Menganalisis dan mengevaluasi ide-ide matematika teman sekelas atau orang lain yang disampaikan 
kepadanya, (4) Menggunakan bahasa matematika untuk memamparkan ide matematikanya secara tepat dan jelas (NCTM, 2000).

Indikator kemampuan komunikasi matematis siswa menurut NCTM adalah sebagai berikut: (a) Kemampuan mengekspresikan ide-ide matematis melalui lisan, tulisan, dan mendemonstrasikannya serta menggambarkannya secara visual. (b) Kemampuan memahami, menginterpretasikan, dan mengevaluasi ide-ide matematis baik secara lisan, tulisan, maupun dalam bentuk visual lainnya. (c) Kemampuan dalam menggunakan istilah-istilah, notasi-notasi matematika dan struktur-strukturnya untuk menyajikan ide-ide, menggambarkan hubungan hubungan dengan model-model situasi (Fachrurazi, 2011). Selanjutnya Greenes dan Schulman mengatakan bahwa kemampuan komunikasi matematika dapat terjadi ketika siswa (1) menyatakan ide matematika melalui ucapan, tulisan, demonstrasi dan melukiskannya secara visual dalam tipe yang berbeda; (2) memahami, menafsirkan, dan menilai ide yang disajikan dalam tulisan, lisan atau dalam bentuk visual; (3) mengkonstruk, menafsirkan dan menghubungkan bermacam-macam representasi ide dan hubungannya (Hoiriyah, 2017). Untuk merealisasikan kemampuan yang akan dimiliki siswa perlu diterapkan pola pendekatan dalam pembelajaran yang mendorong siswa lebih aktif.

Pendekatan Realistic Mathematics Education (RME), salah satu pendekatan dalam pembelajaran yang memberikan kesempatan luas kepada peserta didik untuk beraktivitas sesuai dengan kemampuan yang dimiliki siswa itu sendiri. Pendekatan RME sangat menganjurkan dalam proses pembelajaran menggunakan konteks alam sekitar menjadi objek pembelajaran didalam kelas.

Ada lima ciri-ciri khusus pendekatan Realistic Mathematic Eduation yaitu: (a) Memanfaatkan konteks, maksudnya sewaktu proses pembelajaran matematika realistik berlangsung kondisi alam sekitar yang menjadi tempat keseharian atau pengetahuan yang telah dimiliki siswa dapat digunakan menjadi bagian materi belajar bagi siswa. (b) Menggunakan model, setiap permasalahan dan gagasan yang terjadi dalam kehidupan sehari-hari dapat dinyatakan dalam bentuk model matematika, baik dari situasi nyata maupun yang mengarah ke tahap abstrak. (c) Memanfaatkan ide/gagasan siswa, artinya penyelesaian masalah yang dilakukan siswa atau penemuan konsep berdasarkan sumbangan gagasan siswa. (d) Interaktif, maksudnya kegiatan selama proses pembelajaran didasarkan komunikasi dua arah antar siswa dengan siswa, siswa dengan pendidik dan siswa dengan kondisi alam sekitar. (e) Intertwinment, maksudnya materi-materi yang berbeda dapat diintegrasikan sehingga dapat menghasilkan pemahaman suatu konsep secara utuh dan berkesinambungan (De Lange, 1987).

Berbagai uraian diatas memberikan gambaran bahwa RME berpotensi untuk meningkatkan pemahaman matematika, keterampilan komputasi, serta kemampuan pemecahan masalah siswa. Dan diketahui bahwa tingkat tertinggi 
dari pemahaman konsep adalah mampu memecahkan masalah. Dengan demikian RME dipandang sebagai pendekatan yang tepat dalam mengembangkan kemampuan pemahaman konsep siswa, karena mampu memecahkan masalah matematik.

Selain RME, Contextual Teaching and Learning (CTL) juga dianggap mampu untuk meningkatkan kemampuan pemahaman konsep dan komunikasi matematis siswa. Contextual Teaching and Learning merupakan pendekatan pembelajaran yang mengutamakan aktivitas siswa secara secara mandiri dalam kegiatan proses belajar mengajar sehingga dapat memaknai bahan yang dipelajari dengan mengaitkan kepada situasi kehidupan nyata (Sanjaya, 2010).

Pendekatan kontekstual menurut (Siti Halimah, 2008) adalah konsep belajar yang membantu guru mengaitkan antara materi yang diajarkannya dengan situasi dunia nyata siswa dan mendorong siswa membuat hubungan antara pengetahuan yang dimilikinya dengan penerapannya dalam kehidupan mereka sehari-hari. Sejalan dengan itu dalam (Undang-Undang NO. 20, 2003) disebutkan bahwa pendekatan pembelajaran kontekstual (Contextual Teaching and Learning) adalah konsep belajar yang membantu guru mengaitkan antara materi yang diajarkannya dengan situasi dunia nyata peserta didik dan mendorong peserta didik membuat hubungan antara pengetahuan yang dimiliknya dengan penerapannya dalam kehidupan mereka sehari-hari, dengan melibatkan tujuh komponen utama pembelajaran efektif, yakni kontruktivisme (Contructivism), bertanya (Questioning), menemukan (Inquiry), masyarakat belajar (Learning Community), pemodelan (Modeling), refleksi (Reflection), dan penilaian sebenarnya (Authentic Assessment).

CTL juga merupakan suatu pendekatan pembelajaran yang memberikan fasilitas kegiatan belajaran siswa untuk mencari, mengolah dan menemukan pengalaman belajar yang lebih bersifat kongkrit (terkait dengan kehidupan nyata) melalui keterlibatan aktivitas siswa dalam mencoba, melakukan dan mengalami sendiri (learning by doing). Oleh karenanya dalam komunikasi matematis yang bersifat konvergen dan mengandung unsur koopertatif (cooperative learning) maka CTL dianggap suatu pendekantan pembelajaran yang tepat digunakan untuk meningkatkan kemampuan komunikasi matematis siswa.

Berdasarkan hal di atas, peneliti tertarik untuk melakukan suatu penelitian terkait dengan Pengaruh Pendekatan Pembelajaran Realistic Mathematics Education dan Contextual Teaching Learning terhadap pemahaman konsep dan komunikasi matematis. yang dianggap sebagai solusi yang mampuh mempegaruhi siswa dalam memahami suatu konsep dan mampu untuk mengkomunikasikan konsep tersebut dalam pemecahan masalah sehari-hari. 


\section{METODE PENELITIAN}

Lokasi yang menjadi tempat penelitian ini adalah SMA PAB Medan Estate TA 2018/2019. Penelitian ini dilaksanakan dengan menggunakan pendekatan kuantitatif, sedangkan jenis penelitiannya adalah quasi eksperimen dengan teknik pengambilan sampel menggunakan total cluster random sampling. Hal ini digunakan karena sampel yang sudah terbentuk sendiri, yaitu kelas $\mathrm{X}_{1}$ dan $\mathrm{X}_{2}$ dengan memilih dua kelas yang diajarkan oleh guru yang sama. Kelas $\mathrm{X}_{1}$ dijadikan kelas eksperimen 1 dengan menerapkan RME dan $\mathrm{X}_{2}$ dijadikan kelas eksperimen 2 dengan menerapkan CTL.

Penelitian ini dilakukan dengan desain 2 variabel bebas yaitu dan Realistic Mathematics Education $\left(X_{1}\right)$ dan Contextual Teaching and Learning $\left(X_{2}\right)$ sedangkan 2 variabel terikat yaitu pemahaman konsep $\left(Y_{1}\right)$ dan komunikasi matematis $\left(Y_{2}\right)$.

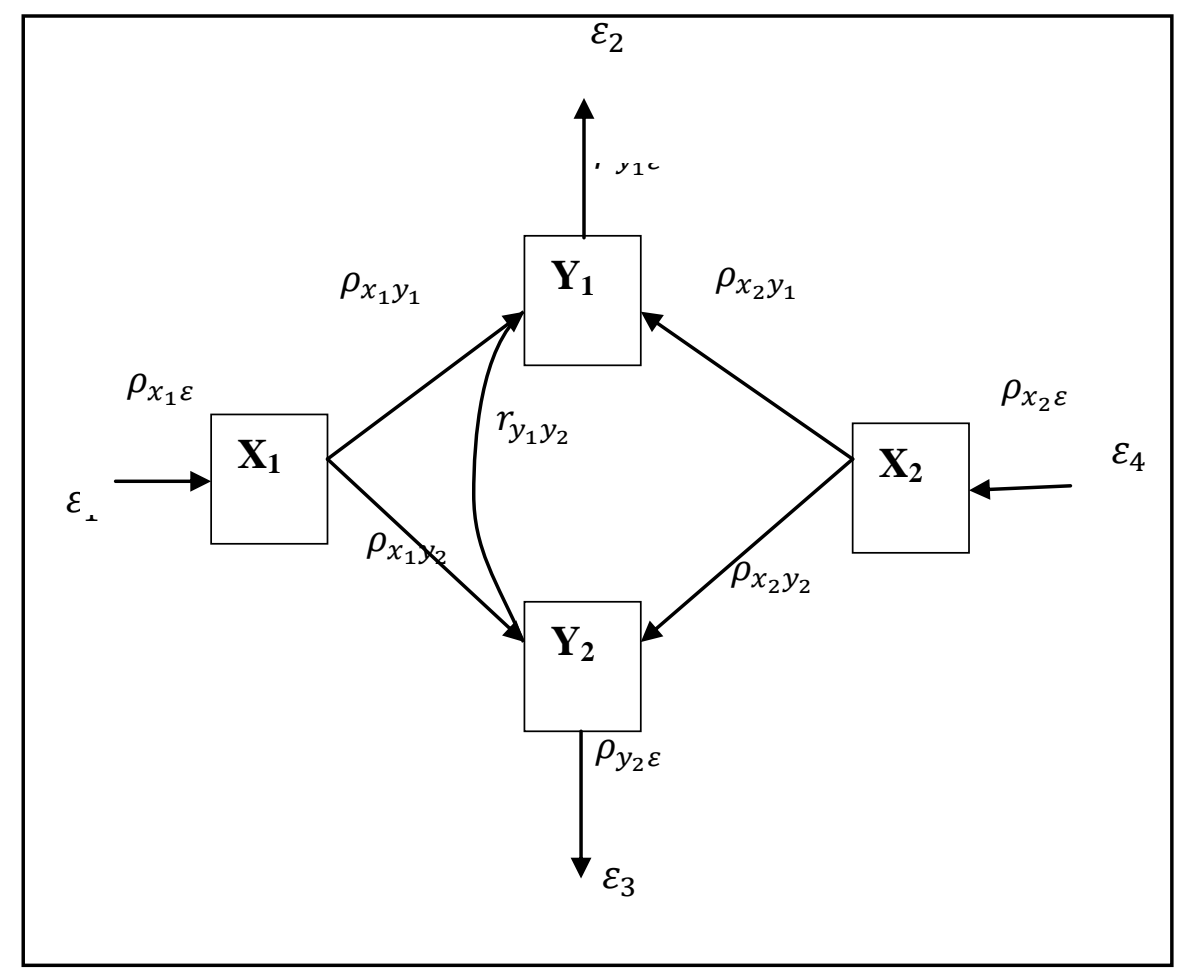

Gambar 1. Diagram Jalur Analisis Penelitian

Instrumen penelitian adalah alat yang digunakan untuk mengumpulkan data-data yang diperoleh dalam penelitian. Adapun yang menjadi instrument dalam penelitian ini adalah soal-soal matematika yang mengacu pada pemahaman konsep dan komunikasi matematis siswa. Sehingga soal-soal yang digunakan dalam penelitian ini adalah soal-soal yang harus berbentuk uraian, karena dengan 
tes yang berbentuk uraian kemampuan siswa dapat dilihat alur pikirnya ataupun proses berpikirnya sewaktu menyelesaikan soal tersebut.

Adapun teknik analisa yang digunakan adalah analisis inferensial. Analisis Inferensial digunakan pada pengujian hipotesis statistik. Sebelum dilakukan pengujian hipotesis, pada kelompok-kelompok dan dilakukan pengujian normalitas, untuk kebutuhan ujian normalitas ini digunakan teknik analisis Kolmogorov-Smirnov. Sedangkan pada analisis uji Homogenitas digunakan teknik analisis dengan perbandingan varians. Kemudian pengujian hipotesis menggunakan ANACOVA. Adapun variabel yang diuji adalah hasil tes pemahaman konsep dan hasil tes kemampuan komunikasi matematis siswa.

\section{HASIL DAN PEMBAHASAN}

Berdasarkan hasil pengumpulan data penelitian quasi eksperimen yang telah dilakukan oleh peneliti, maka dapat dipaparkan data-data yang diperoleh dalam tabel berikut ini:

Tabel 1. RME dan CTL terhadap Pemahaman Konsep dan Komunikasi

\begin{tabular}{|c|c|c|c|c|c|c|}
\hline \multirow[t]{2}{*}{ Kelas } & \multicolumn{2}{|c|}{$\mathrm{X}_{1}$} & \multicolumn{2}{|c|}{$\mathrm{X}_{2}$} & \multicolumn{2}{|c|}{ Total } \\
\hline & $\mathrm{N}$ & $=35$ & $\mathrm{~N}$ & $=35$ & $\mathrm{~N}$ & $=70$ \\
\hline \multirow{4}{*}{$\mathrm{Y}_{1}$} & $\sum \mathrm{X}_{1} \mathrm{Y}_{1}$ & $=2640$ & $\sum \mathrm{X}_{2} \mathrm{Y}_{1}$ & $=2535$ & $\sum \mathrm{Y}_{1}$ & $=5175$ \\
\hline & Mean & $=75.43$ & Mean & $=72.43$ & Mean & $=73.93$ \\
\hline & SD & $=11.006$ & SD & $=10.598$ & SD & $=10.831$ \\
\hline & Var & $=121.134$ & Var & $=112.311$ & Var & $=117.314$ \\
\hline \multirow{5}{*}{$\mathrm{Y}_{2}$} & $\mathrm{~N}$ & $=35$ & $\mathrm{~N}$ & $=35$ & $\mathrm{~N}$ & $=70$ \\
\hline & $\sum \mathrm{X}_{1} \mathrm{Y}_{2}$ & $=2742$ & $\sum \mathrm{X}_{2} \mathrm{Y}_{2}$ & $=2691$ & $\sum \mathrm{Y}_{2}$ & $=5433$ \\
\hline & Mean & $=78.34$ & Mean & $=76.89$ & Mean & $=77.61$ \\
\hline & SD & $=11.417$ & SD & $=11.378$ & $\mathrm{SD}$ & $=11.338$ \\
\hline & Varian & $=130.350$ & Var & $=129.457$ & Var & $=128.559$ \\
\hline \multirow{5}{*}{ Total } & $\mathrm{N}$ & $=70$ & $\mathrm{~N}$ & $=70$ & $\mathrm{~N}$ & $=140$ \\
\hline & $\sum \mathrm{X}_{1}$ & $=5382$ & $\sum \mathrm{X}_{2}$ & $=5226$ & $\sum \mathrm{X}$ & $=10608$ \\
\hline & Mean & $=76.89$ & Mean & $=74.66$ & Mean & $=75.77$ \\
\hline & $\mathrm{SD}$ & $=11.228$ & SD & $=11.143$ & SD & $=11.201$ \\
\hline & Varian & $=126.074$ & Var & $=124.171$ & Varian & $=125.473$ \\
\hline
\end{tabular}


Sebelum dilakukan analisis kovarian atau sering dikatakan ANACOVA, terlebih dahulu dilakukan uji persyaratan. Adapun uji persyaratan ANACOVA diantaranya adalah sebagai berikut:

\section{Uji Normalitas}

Dari hasil pengambilan sampel yang telah dilaksanakan maka dilakukan pengujian. Untuk menguji normalitas data maka digunakan uji Kolmogorovsmirnov. Adapun hasil perhitungan normalitas data untuk setiap kelompok disajikan dalam tabel berikut ini:

Tabel 2. Uji Normalitas Data

\begin{tabular}{ccccl}
\hline \multirow{2}{*}{ Kelas } & \multicolumn{3}{c}{ Kolmogorov-smirnov } & \multirow{2}{*}{ Hasil } \\
\cline { 2 - 4 } & Statistik & $\mathrm{dk}$ & Signifikansi & \\
\hline $\mathrm{X}_{1} \mathrm{Y}_{1}$ & 0,11 & 35 & 0,20 & Normal \\
\hline $\mathrm{X}_{2} \mathrm{X}_{1}$ & 0,11 & 35 & 0,20 & Normal \\
\hline $\mathrm{X}_{1} \mathrm{Y}_{2}$ & 0,11 & 35 & 0,20 & Normal \\
\hline $\mathrm{X}_{2} \mathrm{Y}_{2}$ & 0,11 & 35 & 0,20 & Normal \\
\hline $\mathrm{X}_{1}$ & 0,10 & 70 & 0,19 & Normal \\
\hline $\mathrm{X}_{2}$ & 0,10 & 70 & 0,07 & Normal \\
\hline $\mathrm{Y}_{1}$ & 0,97 & 70 & $0,17^{*}$ & Normal \\
\hline $\mathrm{Y}_{2}$ & 0,11 & 70 & $0,52^{*}$ & Normal \\
\hline
\end{tabular}

Nilai signifikan $p>\alpha=0,05$, artinya sebaran data berdistribusi normal

Berdasarkan tabel di atas, seluruh kelompok memiliki nilai signifikansi $\mathrm{p}$ $>\alpha=0,05$ maka disimpulkan bahwa data berdistribusi normal.

\section{Uji Homogenitas Data}

Uji homogenitas data bertujuan untuk melihat kesetaraan varians seluruh kelas. Baik kelas yang diberikan perlakuan pendekatan pembelajaran Realistic Mathematics Education maupun kelas yang diberikan perlakuan pendekatan pembelajaran Contextual Teaching Learning.

Langkah selanjutnya yang dilakukan adalah uji homogenitas terhadap masing-masing pada sub-sub kelompok sampel yaitu melalui hasil perhitungan uji homogenitas data dengan ketentuan signifikan $(\mathrm{p}>\alpha)$ dengan $\alpha=0,05$ yang berarti data homogen: hasil uji homogenitas , $\mathrm{X}_{1}, \mathrm{X}_{2}$ dengan signifikansi 0,883 atau 0,883 $>0,05$ untuk, $Y_{1}, Y_{2}$ dengan signifikansi 0,486. Sedangkan $X_{1} Y_{1}$, $\mathrm{X}_{2} \mathrm{Y}_{1}, \mathrm{X}_{1} \mathrm{Y}_{2}, \mathrm{X}_{2} \mathrm{Y}_{2}$ diperoleh signifikansi 0,897 , dari hasil uji homogenitas semua 
kelompok lebih besar dari nilai $\alpha=0,05$. Brdasarkan data yang diperoleh tersebut maka dapat disimpulkan bahwa seluruh kelas memiliki varians yang sama (homogen).

\section{Regresi Ganda}

Hasil pengolahan data dengan menggunakan persamaan regresi ganda dengan shofware aplikasi SPSS 25, Pendekatan RME dan CTL didapat nilai hasil tes untuk kelas pemahaman konsep sebesar $\hat{Y}=3,069+1,195 X_{1}+$ $\left(-0,282 X_{2}\right)$ dan Pendekatan RME dan CTL didapat nilai hasil tes untuk kelas komunikasi matematis sebesar $\hat{Y}=2,991+0,536 X_{1}+0,420 X_{2}$.

\section{Uji Keberartian}

Tabel 4. Data Hasil Uji Independent (Keberartian)

\begin{tabular}{|c|c|c|c|c|c|c|c|}
\hline Kelas & Dk & JK & KT & $F_{\text {hitung }}$ & Sig. & $\begin{array}{c}\mathbf{F} \\
\text { tabel }\end{array}$ & Kesimpulan \\
\hline $\begin{array}{l}\operatorname{RME}\left(\mathrm{X}_{1}\right) \\
\text { Pemahaman } \\
\text { Konsep }\left(\mathrm{Y}_{1}\right)\end{array}$ & 1 & $\begin{array}{l}7948, \\
87\end{array}$ & $\begin{array}{l}7948, \\
87\end{array}$ & 635,44 & $\begin{array}{l}0,000 \\
*\end{array}$ & & Berarti \\
\hline $\begin{array}{l}\text { CTL }\left(\mathrm{X}_{2}\right) \\
\text { Pemahaman } \\
\text { Konsep }\left(\mathrm{Y}_{1}\right)\end{array}$ & 1 & $\begin{array}{l}7256, \\
8\end{array}$ & $\begin{array}{l}7256, \\
8\end{array}$ & 335,65 & $\begin{array}{l}0,000 \\
*\end{array}$ & & Berarti \\
\hline $\begin{array}{l}\operatorname{RME}\left(\mathrm{X}_{1}\right) \\
\text { Komunikasi } \\
\text { Matematis } \\
\left(\mathrm{Y}_{2}\right)\end{array}$ & 1 & $\begin{array}{l}8024, \\
44\end{array}$ & $\begin{array}{l}8024, \\
44\end{array}$ & 748,10 & 0,000 & $\begin{array}{l}3,9 \\
82\end{array}$ & Berarti \\
\hline $\begin{array}{l}\operatorname{CTL}\left(\mathrm{X}_{2}\right) \\
\text { Komunikasi } \\
\text { Matematis } \\
\left(\mathrm{Y}_{2}\right)\end{array}$ & 1 & $\begin{array}{l}7848, \\
19\end{array}$ & $\begin{array}{l}7848, \\
19\end{array}$ & 652,26 & $\begin{array}{l}0,000 \\
*\end{array}$ & & Berarti \\
\hline
\end{tabular}

Nilai signifikan $=p<\alpha$, dimana nilai $\alpha=0,05$ maka data berarti

Dari Tabel. 4 diatas, dapat dilihat bahwa ringkasan hasil uji kedua kemampuan yang dilaksanakan didapat untuk pemahaman konsep dan komunikasi matematis, diperoleh dengan koefisien signifikansi regresinya masing-masing didapat sama dengan 0,000. Sehingga 0,000 $<0,05$ atau datanya berarti, maksudnya ada hubungan linear antara kedua kemampuan yaitu kemampuan 
pemahaman konsep dan komunikasi matematis dengan kedua model pembelajaran yang diterapkan yaitu REM dan CTL.

\section{Uji Linearitas}

Kemudian untuk mengetahui apakah penerapan pendekatan RME dan CTL terhadap pemahaman konsep siswa dan komunikasi siswa maka dilakukan uji linearitas yaitu uji regresi. Hasil uji linieritas yang dilaksanakan dirangkum dalam Tabel 5 berikut ini:

Tabel 5. Uji Regresi

\begin{tabular}{|c|c|c|c|c|c|c|c|}
\hline Kelas & dk & JK & KT & $\mathbf{F}_{\text {hitung }}$ & Sig. & $\begin{array}{c}\mathbf{F} \\
\text { tabel }\end{array}$ & Hasil \\
\hline $\begin{array}{l}\mathrm{RME} \quad\left(\mathrm{X}_{1}\right) \\
\text { Pemahaman } \\
\left(\mathrm{Y}_{1}\right)\end{array}$ & 9 & 12,164 & 1,352 & 0,108 & $0,999^{*}$ & \multirow{2}{*}{2,043} & Linear \\
\hline $\begin{array}{l}\text { CTL } \\
\text { Pemahaman } \\
\text { Konsep }\left(\mathrm{X}_{1}\right)\end{array}$ & 9 & 35,386 & 3,932 & 0,182 & $0,995^{*}$ & & Linear \\
\hline $\begin{array}{l}\text { RME } \\
\text { Komunikasi } \\
\text { Matematis }\left(\mathrm{X}_{1}\right)\end{array}$ & 11 & 63,239 & 5,749 & 0,536 & $0,871^{*}$ & & Linear \\
\hline $\begin{array}{l}\text { CTL } \\
\text { Komunikasi } \\
\text { Matematis }\left(\mathrm{X}_{2}\right)\end{array}$ & 11 & 33,745 & 3,068 & 0,255 & $0,991^{*}$ & & Linier \\
\hline
\end{tabular}

Nilai signifikan $=p>\alpha$, dengan $\alpha=0,05$ artinya data linear

Dimana berdasarkan Tabel 5 di atas, diperoleh bahwa dengan penerapan RME dan CTL untuk pemahaman konsep siswa adalah linier. Selanjutnya dengan penerapan RME dan CTL untuk komunikasi komunikasi siswa adalah juga linier.

\section{Uji Hipotesis}

Untuk menganalisis keempat hipotesis yang diajukan dalam penelitian ini, maka digunakan dengan menggunakan ANACOVA. Adapun hasil ANACOVA dapat dilihat deskripsinya dalam tabel sebagai berikut: 
Tabel 6. Data ANACOVA

\begin{tabular}{|c|c|c|c|c|c|c|c|}
\hline \multicolumn{8}{|c|}{ Variabel Dependent: Pemahaman Konsep ( $\left.\mathbf{Y}_{1}\right)$} \\
\hline Variansi & Dk & JK & KT & $\mathbf{F}_{\text {hitung }}$ & Sig. & $\begin{array}{c}\mathbf{F} \\
\text { tabel } \\
\end{array}$ & Hasil \\
\hline Intercept & 1 & 6,349 & 6,349 & 1,216 & 0,274 & & $\begin{array}{l}\text { Tidak } \\
\text { Berarti }\end{array}$ \\
\hline $\begin{array}{l}\text { Cov } \\
\text { Komunikasi } \\
\text { Matematis } \\
\left(\mathrm{Y}_{2}\right)\end{array}$ & 1 & 8200,781 & 8200,781 & 1571,316 & $0,000^{*}$ & 3,978 & Berarti \\
\hline $\begin{array}{l}\text { Pendekatan } \\
\text { Pembelajaran } \\
(\mathrm{X})\end{array}$ & 1 & 324,965 & 324,965 & 62,265 & $0,000^{*}$ & & Berarti \\
\hline Error & 67 & 349,676 & 5,219 & & & & \\
\hline Total & 70 & 422498,0000 & & & & & \\
\hline
\end{tabular}

Dari hasil analisis yang telah dilakukan peneliti, terdapat nilai $\mathrm{F}_{\text {hitung }}$ pada variabel Covarian komunikasi matematis adalah sebasar 1571,316 dengan nilai Sig. 0,000, sehingga $0,000<0,05$ sesuai dengan taraf signifikan yakni $F_{\text {hitung }}>$ $\mathrm{F}_{\text {tabel }}$ atau nilai Sig. $<\alpha$. Hal ini memiki maksudn bahwa pada tingkat $95 \%$ bisa dinyatakan terdapat hubungan antara komunikasi matematis dengan pemahaman konsep yang didapat siswa. Sedangkan untuk nilai $\mathrm{F}$ hitung dalam pendekatan pembelajaran adalah 62,265 dan nilai Sig 0,000. Sehingga sig $=0,000<0,05$ sesuai dengan ketentuan bahwa taraf signifikan nilai Sig lebih kecil dari $\alpha$. Sehingga dapat ditarik kesimpulan bahwa pada tingkat $95 \%$ ada pengaruh komunikasi matematis, namun dapat dilihat bahwa ada perbedaan pengaruh pendekatan pembelajaran terhadap hasil pemahaman konsep siswa.

Hasil analisis yang dilakukan menunjukkan bahwa secara bersama komunikasi matematis siswa dan pendekatan pembelajaran yang digunakan berpengaruh terhadap hasil pemahaman konsep matematika.

Pada bagian pembahasan ini diuraikan sejauhmana hasil penelitian ini tercapai. Adapun hasil penelitian ini melihat pengaruh penggunaan model pembelajaran terhadap kemampuan siswa setelah diberikan perlakuan dan dikaitkan dengan teori-teori yang menjadi pendukung dalam penelitian ini sebagai berikut: Pembelajaran yang menggunakan pendekatan CTL lebih baik dibandingkan pendekatan pembelajaran $R M E$ terhadap kemampuan pemahaman konsep dan komunikasi matematis siswa.

Hasnawati mengatakan, pendekatan pembelajaran CTL adalah model pembelajaran yang menekankan pada keterkaitan materi yang dipelajari dengan 
kejadian yang dialami oleh siswa. Walaupun pendekatan pembelajaran ini samasama menekankan pada aktivitas siswa dan dunia nyata, model pembelajaran $R M E$ ini memiliki tahapan yang berbeda sehingga dibutuhkan kemandirian siswa untuk melakukan aktivitas yang ada dalam pendekatan pembelajaran RME siswa harus mampu melakukan yaitu; (a) Memanfaatkan konteks, maksudnya sewaktu proses pembelajaran matematika realistik berlangsung kondisi alam sekitar yang menjadi tempat keseharian atau pengetahuan yang telah dimiliki siswa dapat digunakan menjadi bagian materi belajar bagi siswa. (b) Menggunakan model, setiap permasalahan dan gagasan yang terjadi dalam kehidupan sehari-hari dapat dinyatakan dalam bentuk model matematika, baik dari situasi nyata maupun yang mengarah ke tahap abstrak. (c) Memanfaatkan ide/gagasan siswa, artinya penyelesaian masalah yang dilakukan siswa atau penemuan konsep berdasarkan sumbangan gagasan siswa. (d) Interaktif, maksudnya kegiatan selama proses pembelajaran didasarkan komunikasi dua arah antar siswa dengan siswa, siswa dengan pendidik dan siswa dengan kondisi alam sekitar. (e) Intertwinment, maksudnya materi-materi yang berbeda dapat diintegrasikan sehingga dapat menghasilkan pemahaman suatu konsep secara utuh dan berkesinambungan

Penelitian ini menemukan adanya interaksi pendekatan pembelajaran yang diterapkan dengan pemahaman konsep dan komunikasi matematis siswa. Osterholm (Osterholm, 2006) menyatakan siswa tampaknya kesulitan mengartikulasikan alasan dalam memahami suatu bacaan. Hal ini disebabkan siswa belum terbiasa dengan model pembelajaraan seperti ini, siswa masih terlihat sering kebingungan dan pasif dalam pembelajaran yang dilakukan. Sejalan dengan Susanto pembelajaran siswa dikelas seharusnya dikaitkan dengan pengalaman konteks nyata kehidupan setiap hari peserta didik.

\section{KESIMPULAN}

Kesimpulan yang dapat dikemukakan dalam penelitian ini adalah sebagai berikut; bahwa pemahaman konsep siswa yang diberi perlakuan dengan pendekatan $R M E$ lebih rendah pengaruhnya daripada siswa yang diberi perlakuan pendekatan $C T L$. Tingkat komunikasi matematis siswa yang diberi perlakuan pendekatan $R M E$ lebih rendah pengaruhnya daripada yang siswa diberi perlakuan pendekatan CTL. Pemahaman konsep dan komunikasi matematis siswa yang diberi perlakuan pendekatan pembelajaran $R M E$ lebih rendah pengaruhnya daripada siswa yang diberi perlakuan pendekatan pembelajaran CTL.

Selanjutnya analisis data menyimpulkan terdapat pengaruh interaksi penerapan pendekatan pembelajaran terhadap pemahaman konsep dan komunikasi matematis siswa. Pendekatan pembelajaran yang mengedepankan aktivitas siswa dalam pembelajaran harus lebih ditingkatkan oleh guru, agar dapat membangkitkan motivasi dan meningkatkan semangat siswa dalam memahami 
konsep dan komunikasi matematis lebih baik dan semakin tumbuh dan berkembang.

\section{DAFTAR PUSTAKA}

Abdullah, A. H., Mokhtar, M., Halim, N. D. A., Ali, D. F., Tahir, L. M., \& Kohar, U. H. A. (2017). Mathematics Teachers' Level of Knowledge and Practice on the Implementation of Higher-Order Thinking Skills (HOTS). Eurasia Journal of Mathematics, Science \& Technology Education, 13(1).

Chotimah, S., Bernard, M., \& Wulandari, S. M. (2018). Contextual approach using VBA learning media to improve students' mathematical displacement and disposition ability. Journal of Physics: Conference Series, 948(1), 012025 .

De Lange, J. (1987). Mathematics, Insight And Meaning. Utrecht: OW \&OC.

Fachrurazi. (2011). Penerapan Pembelajaran Berbasis Masalah untuk Meningkatkan Kemampuan Berpikir Kritis dan Komunikasi Matematis Siswa Sekolah Dasar. Jurnal Universitas Pendidikan Indonesia, Edisi Khus(1).

Firdaus, F. M. (2017). Improving Primary Students' Mathematical Literacy through Problem Based Learning and Direct Instruction. Educational Research and Reviews, 12(4), 212-219.

Guerreiro, A. (2008). Communication in Mathematics Teaching and Learning: Practices in Primary Education.

Hoiriyah, D. (2017). Komunikasi Matematis dalam Pembelajaran Matematika. Logaritma : Jurnal Ilmu-Ilmu Pendidikan Dan Sains, 5(01), 94-108.

NCTM. (2000). Priciples and Standards for Schools Mathematics. Reston, Virginia: NCTM.

Osterholm, M. (2006). Metakognition and reading-criteria for comprehension of mathematics texts. In Novotna, J., Moraova, H., Kratka, M. \& Stehlikova, N. (Eds.). In Proceedings 30th Conference of the Internatinal Group for the Psychology of Mathematics Education (pp. 289-296). Prague: PME.

Rustam, A., \& Handayani, A. L. (2017). Efectivity of Contextual Learning towards Mathematical Communication Skills of the 7th Grade of Smpn 2 Kolaka. Journal of Mathematics Education, 2(1), 1-10.

Sanjaya, W. (2010). Strategi Pembelajaran Berorientasi Proses Pendidikan. Jakarta: Kencana Prenada Media Group.

Simamora, R. E., Sidabutar, D. R., \& Surya, E. (2017). International Journal of 
Sciences: Basic and Applied Research (IJSBAR). Improving Learning Activity and Students' Problem Solving Skill through Problem Based Learning (PBL) in Junior High School, 33(2), 321-331.

Siti Halimah. (2008). Strategi Pembelajaran. Bandung: Cipta Pusaka Media Perintis.

Syarifatunnisa. A. (2013). Perbedaan Kemampuan Pemahaman Matematis antara Siswa yang Mendapatkan Model Pembelajaran Kooperatif Student Teams Achievement Divisions (STAD) dan Tipe Jigsaw. STKIP.

Tong, D. H., \& Loc, N. P. (2017). Students'Errors in Solving Matemathical Word Problems and Their Ability in Identifying Errors in WRrong Solutions. European Journal of Education Studies.

Undang-Undang NO. 20. (2003). tentang Sistem Pendidikan Nasional.

Waldron, J. (2017). Is the rule of law an essentially contested concept (in Florida)? In In The Rule of Law and the Separation of Powers (pp. 117-144). Routledge. 